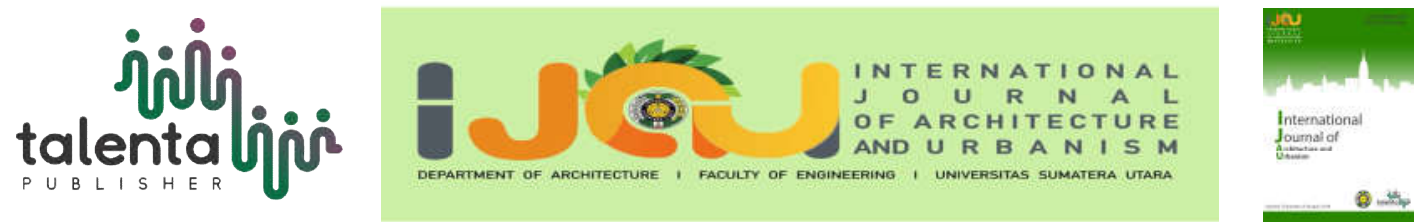

\title{
Evaluation of Passive Fire Protection System on Housing Environment (A Case Study: Perumnas Helvetia Medan)
}

\author{
N. Vinky Rahman ${ }^{*}$, Tika Oktaviani ${ }^{1}$ \\ ${ }^{I}$ Department of Architecture, Universitas Sumatera Utara, Medan, Indonesia
}

\begin{abstract}
Nowadays, housing development wide-spreads in various cities in Indonesia. This is due to the increasing needs of the community towards a safe residence with its complete facilities and infrastructure to support the needs of daily life. Housing is not only build and construct, but it should also have a protection effort to make residential shelter safe from disaster, such as fire. Fires in housing have a high level of risk and danger since it can cause material loss and loss of life. Fire passive protection system is an effort to overcome the fire. The use of passive fire protection system is to facilitate the community and firefighters in extinguishing the fire so that the spread of fire does not propagate to other buildings. The purpose of this study is to evaluate the reliability level of passive fire protection system in the housing environment by doing a case study at Perumnas Helvetia Medan. Then, it was done by giving layout design recommendation of the residential area by passive fire protection system theory of building and environment.
\end{abstract}

Keyword: passive fire protection, housing

\section{Introduction}

Along with the rapid development, the risk of fire will increase. Not a few who suffered losses due to fire, either material loss or casualties. Currently, in Medan, there are some housing that has been built and some in the development planning process. Housing development in Medan City makes people prefer to live and live in housing. To cope with fires, there are two fire protection systems that can be applied to the building that is active fire protection system and fire passive protection system. In principle, fire prevention is preferred to the passive protection system first and then undertakes an active protection system to cope with fire [3]. Fire passive protection systems are fire protection systems that are established or built through the regulation of the use of building materials and components, compartmentalization or building separators based on the level of fire resistance, and protection of openings [5]. The purpose of this study is to evaluate the passive fire protection system in housing environment. Then, it was done by giving a recommendation improvement of the problems in the location by the theory of environmental fire passive protection system.

\footnotetext{
*Corresponding author at: Department of Architecture, Faculty of Engineering, Universitas Sumatera Utara,

Jalan Perpustakaan Gedung J07, Medan 20155, Indonesia

E-mail address: vinkyrahman@gmail.com
} 


\section{Literature Review}

In general, anything that was built and became a shelter someone in it can be considered as a building. Buildings have different forms by the functions that have been set by the government. Increased housing construction led to the availability of land is reduced, this causes more high land prices [1]. Fire disaster is a threat that gives negative impact and loss to human and environment. Building fires are usually caused by various factors, and it happens caused by the owner of the building itself. The disadvantage of building fires is not just about property, but a loss of life. Therefore, the fire cannot be regarded as a trivial issue. To prevent the occurrence of fire, fire prevention efforts are required through fire protection system. Fire protection system is divided into two systems of protection, which is an active fire protection system and passive fire protection systems.

In this research, the evaluation was conducted to obtain a decision in the form of passive fire protection systems reliability value that refers to the arrangement of the housing environment for fire prevention and suppression. Passive fire protection system is a fire protection system that is formed or built up through regulating the use of materials and structural components of the building, compartmentalization or separation of the building based on the degree of fire resistance, as well as the protection of openings [5].

\section{Methodology}

In this study, the method used is descriptive observation, it means direct observation and makes initial conclusions that include the components of the passive fire protection system environment, then restrict the observation and describe the focus of the problem into more detail with the characteristics of each component [4]. During the observation, the data collected are qualitative and the measurement basis assesses the reliability using the subjective scale, then to obtain objective data used AHP (Analytical Hierarchy Process) method. The principle of AHP (Analytical Hierarchy Process) method is a simplification of a complex problem that is not structured, strategic and dynamic into its parts, and arrange in a hierarchy. Then, the level of importance of each variable given a numerical value subjectively about the significance of these variables relative to the other variables. Then, do the synthesis from these considerations to define a variable that has a high priority and serves to influence the outcome of the system. AHP allows the user to give a relative weight value of compound criteria (or a compound to criterion) intuitively, by performing pairwise comparisons [2].

Preparation of the hierarchy is done by outlining the elements that criteria, then organized into a hierarchical structure (Figure 1). 


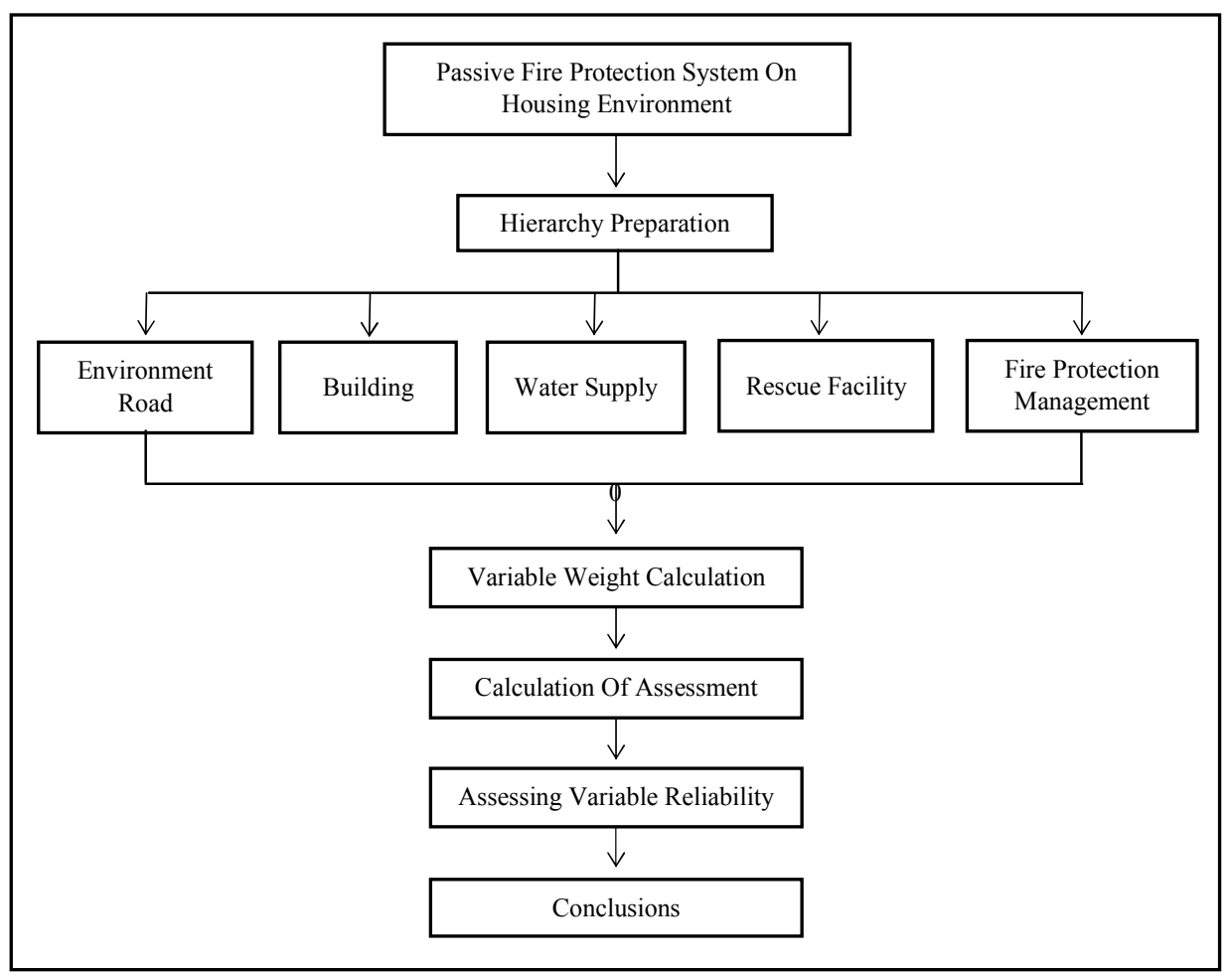

Figure 1. Framework Thinking

Variables passive fire protection systems to be assessed reliability are roads, buildings, water supply and means of rescue. These four components are hierarchies that will be assessed through pairwise comparisons. For various issues, the scale 1 to 9 is the best scale in expressing opinions [2]. Assessment using a scale of 1 to 9 is used in calculating the weight rating on Expert Choice software. In assessing the level of reliability of passive fire protection systems environment, the value of condition variables and sub-variables are divided into four levels (Table 1). Then, the total value of reliability assessment passive fire protection system environment divided into seven levels grade (Table 2).

Table 1. Components Reliability Assessment

\begin{tabular}{|c|l|}
\hline Grade & \multicolumn{1}{|c|}{ Explanations } \\
\hline 1 & $\begin{array}{l}\text { There are no components of passive fire protection system } \\
\text { environment. }\end{array}$ \\
\hline 2 & $\begin{array}{l}\text { There are some components of passive fire protection system } \\
\text { environment, but not standardized. }\end{array}$ \\
\hline 3 & $\begin{array}{l}\text { There are components of passive fire protection system } \\
\text { environment and standardized. }\end{array}$ \\
\hline 4 & \begin{tabular}{l} 
There are all components that standardized. \\
\hline
\end{tabular} \\
\hline
\end{tabular}


Table 2. Grade of Total Component Reliability Values

\begin{tabular}{|c|c|}
\hline Grade & Explanations \\
\hline $1 \leq \mathrm{x}<1,5$ & Worst \\
\hline $1,5 \leq \mathrm{x}<2$ & Very Bad \\
\hline $2 \leq \mathrm{x}<2,5$ & Bad \\
\hline $2,5 \leq \mathrm{x}<3$ & Fair \\
\hline $3 \leq \mathrm{x} \leq 3,5$ & Good \\
\hline $3,5 \leq \mathrm{x} \leq 4$ & Very Good \\
\hline$=4$ & Best \\
\hline
\end{tabular}

\section{Result and Discussion}

Perumnas Helvetia is a medium type of housing that was built in 1977. The layout of Perumnas Helvetia is in the district of Medan Helvetia, Village Central Helvetia, West Medan, North Sumatera and has an area of $\pm 97 \mathrm{Ha}$ and the research sample of this study is palm street, block 10 (Figure 2).

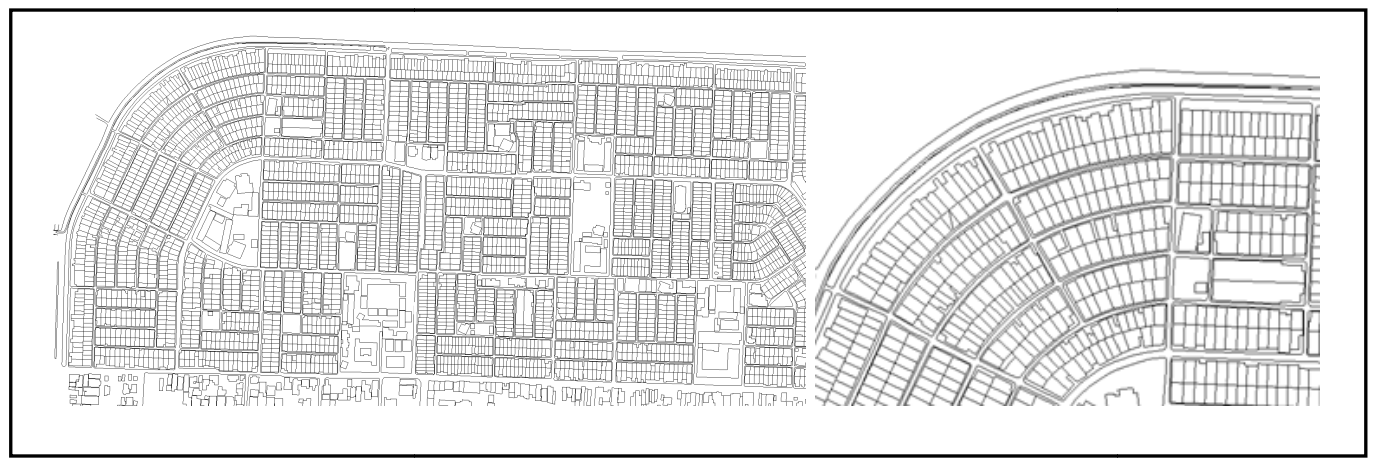

Figure 2. Layout of Perumnas Helvetia

Perumnas Helvetia had some homes that a lot and huddled together. Pavement is the only asphalt without sidewalks. Housing is surrounded by common traffic which has two vehicle lanes. Residential access point through 3 public road lane is Kapten Sumarsono street, Kapten Muslim street, and Matahari Raya street. The small streets to get into the housing has a width of 3-4 meters with asphalt pavement. Facility located in the housing is a school (elementary through high school), mosques, churches, the madrasas, sports grounds, stalls or shops, markets, etc. Also equipped with a drainage channel system, state electricity company, taps and gas pipelines, while the facilities for fire prevention is not seen in this housing (Figure 3). 


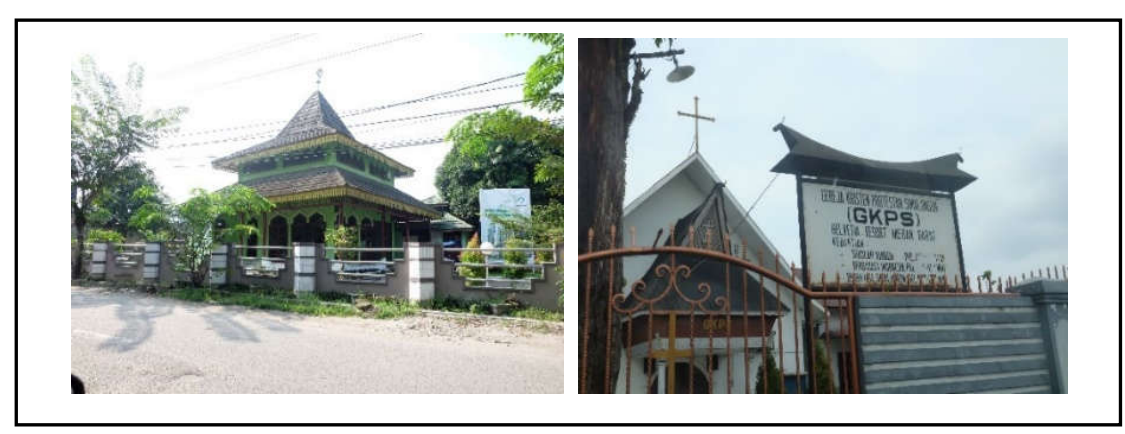

Figure 3. Housing Facilities

The condition of the resident houses on palm street is that the houses are close to each other, so there is no distance between buildings. Building materials used in its structure elements are brick walls plastered. For elements of doors and windows, the material used is wood and glass, while the roof elements using zinc. Type of housing home on variety, but many changes were made by the owner. Perumnas Helvetia is one of the housings that is not visible to apply passive fire protection systems environment. From the calculation of Expert Choice software, known weight rating for components and sub-variables of passive fire protection systems environment that includes roads, buildings, water supply and means of rescue (Table 3).

Table 3. Weight Valuation of Each Component

\begin{tabular}{|l|c|}
\hline $\begin{array}{c}\text { Component Fire Passive Protection } \\
\text { Systems On Environment }\end{array}$ & Weight \\
\hline Environment Road [0.345] & 0.328 \\
\hline - Pavement Coat & 0.182 \\
\hline - Depth Of Pavement Coat & 0.211 \\
\hline - The Outer Radius Of Entrance & 0.278 \\
\hline - Obstacle Free Path & 0.120 \\
\hline Building [0.289] & 0.208 \\
\hline - Distance Between Buildings & 0.602 \\
\hline - Fire Resistant Construction & 0.069 \\
\hline - Building Materials & \\
\hline - Fire Distribution & 0.665 \\
\hline Water Supply [0.031] & 0.090 \\
\hline - Outdoor Hydrant & 0.245 \\
\hline - Outdoor Hydrant Operational & \\
\hline - Other Water Source & 0.330 \\
\hline Rescue Facility [0.046] & 0.391 \\
\hline - Evacuation Room & 0.278 \\
\hline - Evacuation Barrier & 0.605 \\
\hline - Accessibility of Residents & 0.105 \\
\hline Fire Protection Management [0.288] \\
\hline - Fire Protection Organisation \\
\hline - Human Resources & 0.291 \\
\hline - Development Fire Training \\
\hline \multicolumn{2}{|l}{} \\
\hline
\end{tabular}


The reliability of passive fire protection system is carried out by multiplying the weight and reliability rating scale. Here are the results of the sub-variables reliability assessment of passive fire protection systems in the neighborhood Perumnas Helvetia (Table 4).

Table 4. Total Weight Valuation of Grade Component

\begin{tabular}{|c|c|c|c|c|}
\hline $\begin{array}{c}\text { Component Fire Passive Protection } \\
\text { Systems On Environment }\end{array}$ & Value & Weight & Amount & Total \\
\hline \multicolumn{5}{|l|}{ Environment Road [0.345] } \\
\hline - Pavement Coat & 2 & 0.328 & 0.656 & \multirow{4}{*}{1.605} \\
\hline - Depth Of Pavement Coat & 1 & 0.182 & 0.182 & \\
\hline - The Outer Radius Of Entrance & 1 & 0.211 & 0.211 & \\
\hline - Obstacle Free Path & 2 & 0.278 & 0.556 & \\
\hline \multicolumn{5}{|l|}{ Building [0.289] } \\
\hline - Distance Between Buildings & 1 & 0.120 & 0.120 & \multirow{4}{*}{1.207} \\
\hline - Fire Resistant Construction & 2 & 0.208 & 0.416 & \\
\hline - Buildings Materials & 1 & 0.602 & 0.602 & \\
\hline - Fire Distribution & 1 & 0.069 & 0.069 & \\
\hline \multicolumn{5}{|l|}{ Water Supply [0.031] } \\
\hline - Outdoor Hydrant & 1 & 0.665 & 0.665 & \multirow{3}{*}{1.000} \\
\hline - Outdoor Hydrant Operational & 1 & 0.090 & 0.090 & \\
\hline - Other Water Source & 1 & 0.245 & 0.245 & \\
\hline \multicolumn{5}{|l|}{ Rescue Facility [0.046] } \\
\hline - Evacuation Room & 2 & 0.330 & 0.660 & \multirow{3}{*}{1.998} \\
\hline - Evacuation Barrier & 2 & 0.391 & 0.782 & \\
\hline - Accessibility of Residents & 2 & 0.278 & 0.556 & \\
\hline \multicolumn{5}{|l|}{ Fire Protection Management [0.288] } \\
\hline - Fire Protection Organisation & 1 & 0.605 & 0.605 & \multirow{3}{*}{1.001} \\
\hline - Human Resources & 1 & 0.105 & 0.105 & \\
\hline - Development Fire Training & 1 & 0.291 & 0.291 & \\
\hline
\end{tabular}

The results from the multiplication of the weight and value of the reliability of the variable will be summed back by multiplying the weight of components of passive fire protection systems environment (Table 5).

Table 5. Value of Passive Fire Protection System on Environment Reliability

\begin{tabular}{|l|c|c|c|}
\hline $\begin{array}{c}\text { Component Passive Fire } \\
\text { Protection System On } \\
\text { Environment }\end{array}$ & $\begin{array}{c}\text { Valu } \\
\text { e }\end{array}$ & $\begin{array}{c}\text { Weig } \\
\text { ht }\end{array}$ & $\begin{array}{c}\text { Amou } \\
\text { nt }\end{array}$ \\
\hline Environment Road & 2 & 0.345 & 0.690 \\
\hline Building & 1 & 0.289 & 0.289 \\
\hline Water Supply & 1 & 0.031 & 0.031 \\
\hline Rescue Facility & 2 & 0.046 & 0.092 \\
\hline Fire Protection Management & 1 & 0.288 & 0.288 \\
\hline Total & & $\mathbf{1 . 3 9 0}$ \\
\hline
\end{tabular}




\section{Conclusion}

From the calculation of the value reliability of passive fire protection system can be seen that the components of passive fire protection systems in Perumnas Helvetia is worst (1.309), which means this housing does not have components of passive fire protection system by environmental standards and reference the theory of passive fire protection system. This problem causes passive fire protection system on that research site should be attempted restoration. Here is the conclusion of the component analysis of passive fire protection system on housing environment. The first component is Environmental Roads component, gets reliability value 1.605 (Very Bad). This matter because the availability of components does not meet the standards and theories of passive fire protection system on housing environmental. The second component is Building component; this component gets reliability value 1.207 (Very $\mathrm{Bad})$. This matter because the component is not available at the research location. The third component is Water Supply; this component gets reliability value 1.000 (Worst). This matter because the component is not available at the research location. The fourth component is Rescue Facility; this component gets reliability value 1.998 (Very Bad). This matter because the availability of component does not meet the standards and theories of passive fire protection system on housing environment. Then, the last component is Fire Protection Management; this component gets reliability value 1.001 (Very Bad). This matter because the component is not available at the research location.

\section{Acknowledgment}

This research is part of the requirement to obtain a bachelor's degree in the Architecture Department of Universitas Sumatera Utara.

\section{REFERENCES}

[1] R. Adiwidjaja. Studi Tingkat Keandalan Sistem Proteksi Kebakaran Pada Bangunan Apartemen (Studi Kasus Apartemen Di Surabaya). DIMENSI (Journal of Architecture and Built Environment), 39(1), 15-22. 2012.

[2] P. D. Marimin. Teknik dan Aplikasi Pengambilan Keputusan Kriteria Majemuk. Jakarta: Gramedia Widiasarana Indonesia. 2004.

[3] N. V. Rahman. Kajian Penerapan Sistem Proteksi Pasif Desain Site Planing. Kajian Penerapan Sistem Proteksi Pasif Desain Site Planing. 2003.

[4] S. Sinulingga. Research Methods. 2011.

[5] D. P. Umum. Persyaratan Teknis Sistem Proteksi Kebakaran Pada Bangunan Gedung dan Lingkungan. Peraturan Menteri Pekerjaan Umum Nomor: 26. PRT/M/2008. Jakarta. 2008. 